\title{
PROSEDUR BRAKHITERAPI INTRAKAVITER HIGH DOSE RATE PADA KANKER SERVIK
}

\author{
Himawan Setyono ${ }^{1}$ Dwi Sugeng Supriyadi ${ }^{2}$ Dria Wanadi $^{3}$ \\ ${ }_{1,2,3}$ Radiotherapy Department, Regional General Hospital Dr. Moewardi, Indonesia \\ Corresponding author: Himawan Setyono \\ Email: mas_hima1@yahoo.co.id
}

\begin{abstract}
Background: Radiotherapy hold an important role in cervical cancer treatment. The majority of cervical cancer treatment will be more effective with combination of teletherapy and brachitherapy. In radiotherapy installation facility of Regional General Hospital Dr. Moewardi Surakarta brachitherapy use a high dose rate cobalt 60 . The aim of study is to understand cervical cancer intracavity brachitherapy procedure with high dose rate cobalt 60 radiation.
\end{abstract}

Methods: The method of this research was qualitative researchwith case study approachment by observing, interviewing with radiation oncologist doctor, radiotherapy radiographer and medical physicist, and reviewing patient medical record document, simulator image data, treatment planing system resultand patient exposure data.

Results: The result of this research showed that cervical cancer brachitherapy procedure in radiotherapy installation facility of Regional General Hospital Dr. Moewardi Surakarta is using one intrauterine applicator, and two ovoid applicator. Applicator position verified by $\mathrm{C}$-arm simulator. Dose calculation is done using TPS GZP 3 and manchester system where point with 2x8.5 Gyor 3x7 Gy. The brachitherapy unit used is GZP 3 Cobalt 60 Afterloading TherapyUnit high dose rate.

Conclusions: The reason of using a high dose rate cobalt 60 radiation is to make the time efficient so an optimal result is obtained.

Keyword : cervical cancer; brachiteraphy; high dose rate

\section{Pendahuluan}

Kanker leher rahim merupakan keganasan terbanyak pada wanita di negara-negara berkembang. Hal ini banyak disebabkan karena tingkat pendidikan dan pengetahuan mengenai kanker yang cukup rendah, ditambah dengan kebersihan yang buruk serta berbagai faktor lain, sehingga mengakibatkan sebagian besar pasien datang untuk terapi dalam stadium yang telah lanjut.

Kanker leher rahim pada saat ini telah menjangkiti hampir lima ratus ribu wanita pertahun namun jika hal ini tidak dicegah insidennya akan meningkat menjadi satu juta wanita pertahun. Insiden kanker leher rahim ini juga bertambah seiring dengan meningkatnya populasi penderita HIVI AIDS yang mengalami penggurangan kekebalan imunitas yang berpotensi menambah resiko tinggi.

Pengobatan kanker leher rahim terdiri dari pembedahan, kemoterapi dan terapi radiasi. Terapi radiasi memegang peranan penting dalam penanganan karsinoma leher rahim karena efektif dan efisien dibandingkan dengan pembedahan ditambah kemoterapi, angka mortalitas praktis nol dan morbiditas sangat rendah pada penatalaksanaan yang baik serta tidak menimbulkan rasa takut.

Pemberian radiasi terdiri atas kombinasi radiasi eksterna daerah pelvis dan brakhiterapi. Di Instalasi Radioterapi RSUD Dr. Moewardi Surakarta kombinasi antara radiasi eksterna dan brakhiterapi telah dilakukan pada kanker servik, serta mempunyai frekuensi yang paling tinggi. Untuk pelaksanaan brakhiterapi pada kanker servik atau leher rahim dilakukan dengan teknik intrakaviter menggunakan high dose rate (HDR). Tujuan dari penelitian ini adalah untuk mengetahui prosedur brakhiterapi intrakaviter HDR pada kanker servik di Instalasi Radioterapi RSUD Dr. Moewardi Surakarta. 


\section{Metode}

Jenis Penelitian ini adalah kualitatif pendekatan studi kasus dengan pengambilan data pasien kanker servik. Pengumpulan data dilakukan dengan observasi dan wawancara. Observasi dengan melakukan pengamatan pemeriksaan brakhiterapi pada kanker servik di Instalasi Radioterapi RSUD Dr. Moewardi Surakarta. Wawancara langsung dilakukan dengan dokter onkologi radiasi, radiografer radioterapi dan fisikawan medis. Analisa data dilakukan dengan pengumpulan data, reduksi data, penyajian data dan kemudian penarikan kesimpulan.

\section{Hasil dan Pembahasan}

Kasus pada penelitian ini adalah pasien 51 tahun dengan kanker servik. Pada tanggal 9 Mei 2019 dengan membawa surat pengantar konsultasi dari dokter spesialis obstetri dan ginekologi onkologi, pasien datang ke poliklinik radioterapi dengan diagnosa klinis kanker servik. Di poliklinik radioterapi, oleh dokter onkologi radiasi, pasien dilakukan anamnese dan pemeriksaan dokumen riwayat pasien. Hasil dari pemeriksaan patologi anatomi menunjukan adanya keratinizing squamous cell carcinoma well differentiated. Selanjutnya pasien diberikan pengantar pemeriksaan penunjang radiologi thorak, USG abdomen dan laboratorium darah. Setelah dilakukan pemeriksaan fisik dan penunjang medis, dokter onkologi radiasi merencanakan untuk dilakukan radioterapi eksterna.

Perencanaan radioterapi eksterna pada pasien kanker servik diawali dengan simulator lapangan anteroposterior (AP) dan posteroanterior (PA) dengan dosis 50 Gy 25 fraksi, dosis fraksi perminggu 5x200 cGy. Data dari perencanaan simulator selanjutnya dikirim ke bagian treatment planing system (TPS) untuk dilakukan penghitungan waktu radiasi sesuai dengan dosis yang telah direncanakan dokter onkologi radiasi. Setelah selesai dilakukan radioterapi eksterna 25 kali selanjutnya dilakukan perencanaan radioterapi boster brakhiterapi.

Tindakan brakhiterapi sangat tergantung dari evaluasi post radiasi eksterna yang dilakukan langsung oleh dokter onkologi radiasi, pada kanker yang masih berukuran lebih dari $3 \mathrm{~cm}$ maka untuk bosternya akan dilanjutkan dengan teknik box sytem 4 lapangan, karena radiasi brakhiterapi hanya efektif untuk kanker dengan ukuran kurang dari 3 $\mathrm{cm}$.
Sebelum dilakukan tindakan brakhiterapi pasien dan keluarganya diberi penjelasan tentang jalannya pelaksanaan brakhiterapi serta dipersilahkan untuk menandatangani surat persetujuan dilakukan tindakan brakhiterapi. Setelah mendapatkan persetujuan kemudian dokter onkologi radiasi akan menjadwalkan tanggal tindakan brakhiterapi dan juga mempersiapkan segala pemeriksaan penunjang yang diperlukan, termasuk juga konsulan ke dokter anestesi dan jantung. Sehari sebelum dilakukan tindakan brakhiterapi pasien harus sudah masuk rawat inap untuk melakukan persiapan-persiapan termasuk pengosongan usus besar dan pembersihan area vagina.

Pada hari yang dijadwalkan pasien datang di instalasi radioterapi. Pasien dipersilahkan ke kamar kecil untuk pengosongan vesika urinaria, kemudian pasien masuk ke ruang tindakan pemasangan aplikator untuk dilakukan anestesi spinal. Sebelum tindakan pemasangan alat, radiografer dan perawat mempersiapkan alat dan bahan yang diperlukan. Alat yang dipersiapkan antara lain pesawat $\mathrm{C}$-arm, pesawat afterloading therapy unit, instrument brakhiterapi set, lampu dan meja obsgyn. Bahan yang dipersiapkan antara lain adalah obat-obatan anestesi, oksigen, kontras iopamiro dan barium.

Setelah dilakukan anestesi, pasien diposisikan litotomi yang kemudian dokter onkologi radiasi akan melakukan pemasangan aplikator. Prosedur sebelum pemasangan aplikator yang pertama adalah daerah vulva, vagina dan inguinal disterilkan, dipasang foley kateter dan balon yang diisi kontras iopamiro $3 \mathrm{cc}$ dan udara $1 \mathrm{cc}$ sebagai marker area buli-buli. Selanjutnya memasukan sonde uteri ke dalam servik sampai menyentuh fundus uteri, untuk mengetahui kedalaman, lengkungan sudut dan panjang aplikator tandem yang akan dipasang. Ada 3 jenis aplikator tandem yaitu sudut $15^{\circ}, 30^{\circ}$ dan $45^{\circ}$, yang mana penggunaanya disesuaikan kondisi anatomi dari rahim, antefleksi ataupun retrofleksi. Aplikator tandem segera dimasukan ke servik, kemudian segera dimasukan dua aplikator ovoid samping kanan dan kiri sampai menyentuh portio uteri. Pada aplikator ovoid salah satunya dimasukan marking dummi sebagai penanda posisi kanan dan kiri. Ketiga aplikator dirangkai dalam satu kesatuan. Di bawah aplikator dipasang retraktor untuk memudahkan saat modifikasi posisi aplikator hubunganya dengan dosis organ at risk buli-buli dan rektum. Disekitar retraktor dan aplikator diganjal dengan kasa steril untuk fiksasi. Kateter dan rektal marker dimasukan ke dalam anus. Melalui kateter anus dimasukan larutan kontras 
barium $60 \mathrm{cc}$. Fungsi dari kontras dan rektal marker adala penanda area rektum.

Setelah selesai pemasangan aplikator kemudian pasien dibawa ke ruang simulasi dan penyinaran. Dibuat radiograf area pelvis dengan pesawat $\mathrm{C}$-arm posisi anteroposterior (AP) dan lateral dengan teknik orthogonal, untuk mengetahui posisi aplikator dari organ rektum dan buli-buli.

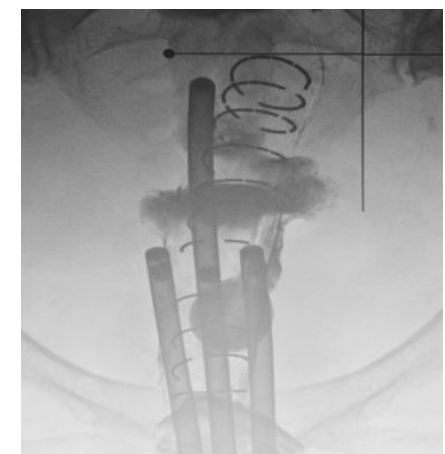

Gambar 1. Hasil radiograf proyeksi AP.

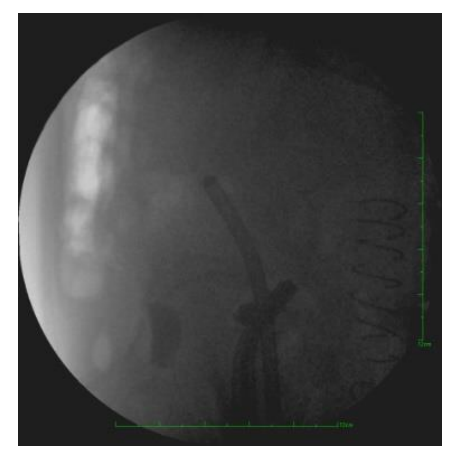

Gambar 2. Hasil radiograf proyeksi lateral.

Setelah selesai simulator hasil dari radiograf dikirim ke bagian TPS untuk penghitungan dosis waktu radiasi. Dosis yang diresepkan adalah $2 \times 850$ cGy atau 3x700 cGy tergantung kondisi hasil penghitungan jangkauan area target dan organ at risk. Metode penghitungan menggunakan Manchester dengan referensi titik A.

Setelah selesai proses penghitungan treatment time radiasi oleh fisikawan medis dan mendapatkan persetujuan dari dokter onkologi radiasi, selanjutnya tube aplikator dihubungkan dengan chanel sumber radiasi untuk dilakukan penyinaran sesuai treatment time yang telah dihitung.

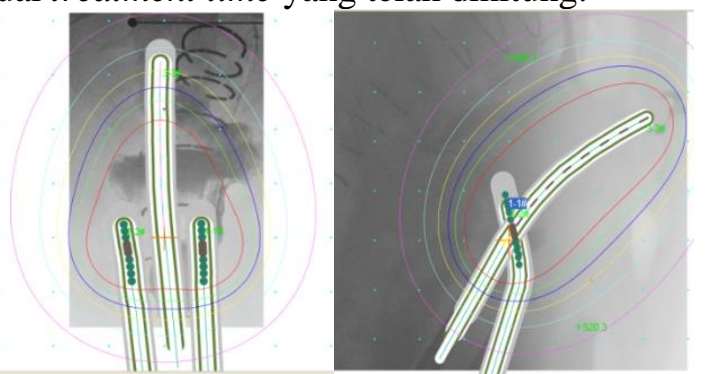

Gambar 3. Kurva isodosis.
Di instalasi radioterapi RSUD Dr. Moewardi untuk tindakan brakhiterapi menggunakan sumber radiasi Cobalt 60 laju dosis tinggi (high dose rate). Dengan sumber radiasi jenis ini akan lebih efisien untuk waktu penyinarannya dan diharapkan mendapatkan hasil yang lebih optimal karena kesempatan pergerakan pasien lebih minimal.

\section{Simpulan}

Prosedur brakhiterapi kanker servik di Instalasi Radioterapi RSUD Dr. Moewardi Surakarta dilakukan melalui beberapa persiapan, antara lain pemeriksaan jantung, laboratorium darah dan puasa untuk pengosongan saluran pencernaan.

Pemasangan aplikator dilakukan dengan dukungan anestesi spinal. Aplikator dipasang oleh dokter onkologi radiasi dengan proses disinfektan area vagina, memasukan foley kateter dan kontras untuk buli-buli. Memasukan sonde uteri kedalam servik sebagai acuan dan untuk memudahkan pemasanagan aplikator. Setelah aplikator terpasang dalam satu rangkaian kemudian dilakukan fiksasi dan pemberian kontras untuk organ rektum.

Setelah pemasangan aplikator, dilakukan simulasi dengan $\mathrm{C}$-arm proyeksi AP dan lateral menggunakan teknik orthogonal. Hasil radiograf ini akan digunakan oleh fisikawan medis untuk penghitungan distribusi.

Tube aplikator dihubungkan dengan chanel sumber radiasi dan dilakukan treatment delivery sesuai waktu yang telah ditentukan pada penghitungan.

\section{Daftar Pustaka}

A. Barret, S. Morris, J. Dobbs, T. Roques. 2009. Practical Radiotherapy Planning. New York: Oxford University Press Inc.

C. Washington, D. Leaver. 2015. Principles and Practice of Radiation Oncology. Massachusetts: Elsevier Health Science Division.

P. Devlin, R. Cormack, C. Holloway, A. Steward. 2016. Brachytherapy: Applications and Techniques. Massachusetts: Lippincott Williams \& Wilkins.

R. Susworo. 2007. Radioterapi. Jakarta: Universitas Indonesia Press. 